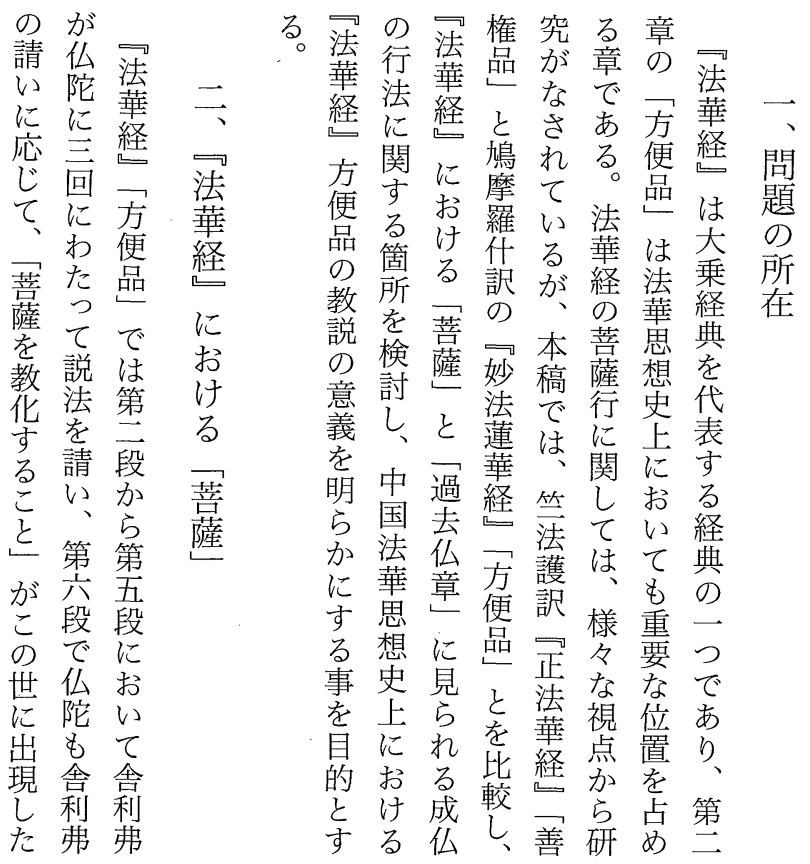

にま文がし、赭其等信是摩者偈薩理 理たる信体者能身護吕法羅訳おと罱 解、信力得 分不訳婜不什をいはあ す教が堅で訳䏬見可奢示訳比ている べ化強固きは解見正者示口較—かこ きの調者る若其亦法天言妙守菩なと か対さ是と芉惟無華正辞法る薩るを 問象れとい異有有経九相蓮と朁も明 題でていうな莘言心箃華落にのら だいう点る薩説五滅経つを加早

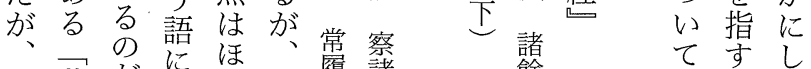
一菩がにぼ、見掌察諸

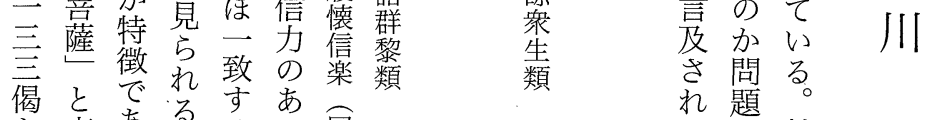
と声 あ る 二聞る。よ方莘六間

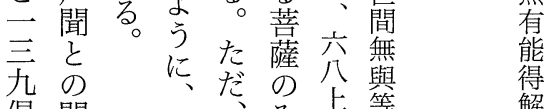
偈関古等 の係法羅が 部を華什法若 分ど経訳を説 をの包の理法 比よに方解時 れ 題教 らな化 员 る る 所、象 が第 と

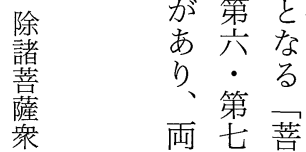


あ聞 羅關て 訳聞 羅則共正無汝妙三皆諸正菩妙三較

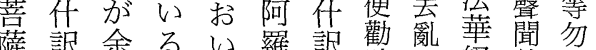
に隡訳余る に の す二に化二薩 、佛狐

る法さの百. と法道疑 過華机対の し華同我 程経て 象漏て成茥同我 同我 十諸

に

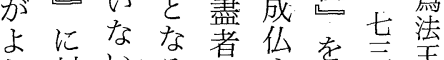
り 対い。る者守聞上主

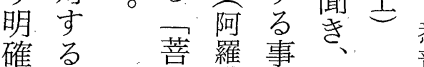
早

II

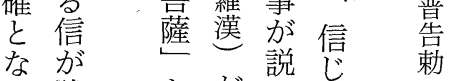

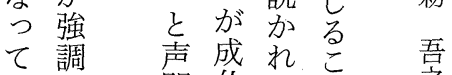

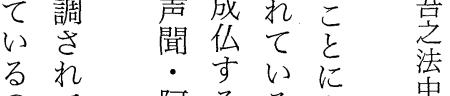

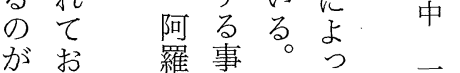
特り、漢が管て、切 徵、と説法、聲 で声の唯声聞

$\begin{array}{ll}\text { 籚 } & \text { 疑 } \\ \text { 佛覩 } \\ \text { 道 } \\ \text { 此 } \\ \text { 皆 }\end{array}$ 同因除

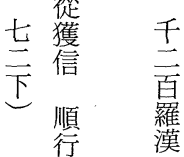

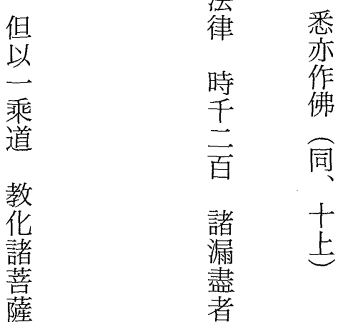

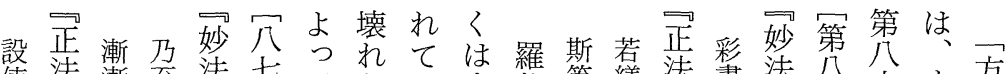

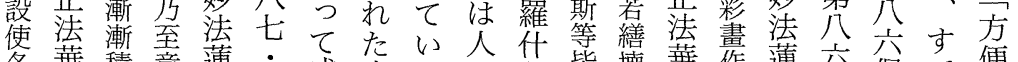

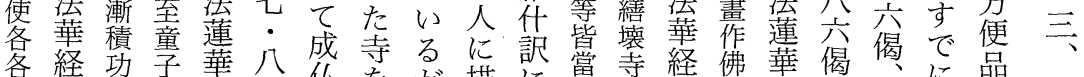

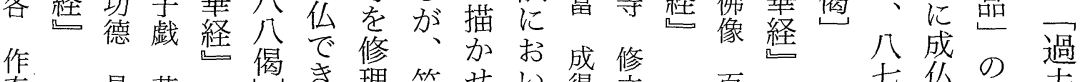

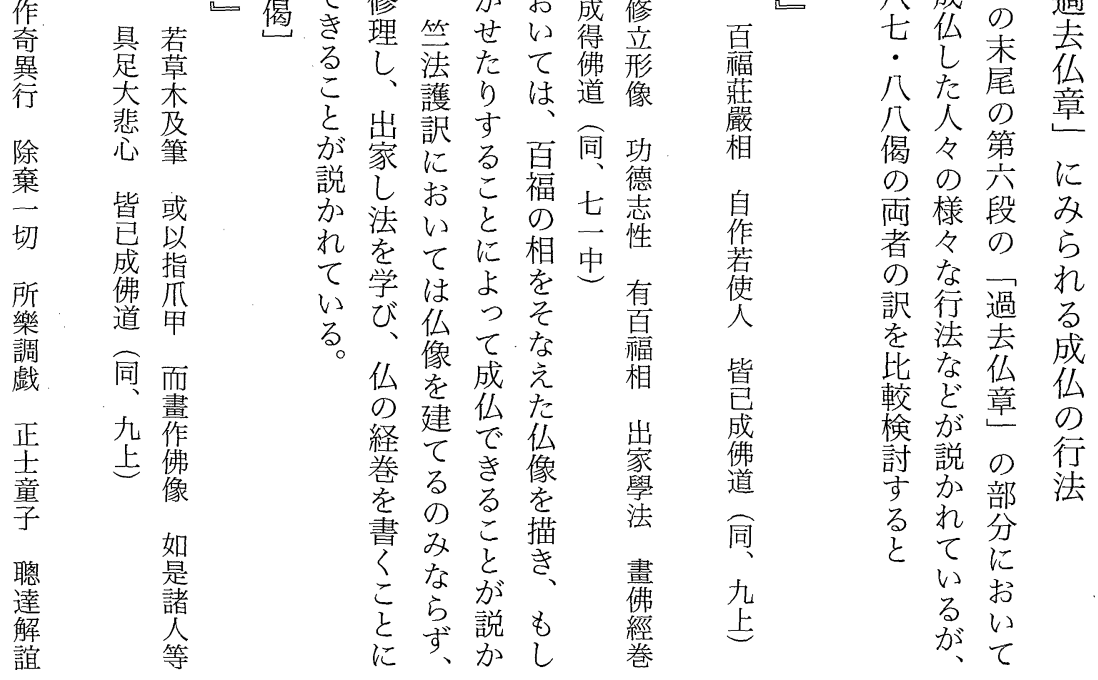


いえ八いらの

たら六管にかる

形れ年法つになの

跡てて護いすらよ はいでがてるずう なるある检た内に くが、、正討め容

翻彼翻華て筷も正 訳が訳程み法著法 協訳を筮る護し華 力経援を事䚳い経 者し助翻に沜違々 とたし訳す摩いと そ際た しる。羅が劣 に講々の 義はは 法や十西 華対三晋 経論人の 凹ので太 の場あ康 思をつ七 想設た年 内 と 容て 伝 三

と る 法 のが蓮 両、華 者こ経 のれに 翻らと違 訳ので点

みの明仏がに 出口確 の 明打以 す 万因確い上 き善形とでて つ同でなあは、法 加帰訳るり、声華 との学齐四聞経 な説て強法が方 $つ や い$ 調華菩方 た、るさ経薩便 言方がれにに品 え点こい対換教 る。釈のるす虽 こ等るてに のと信成つ 二が法や、仏い 乗法華経にて 解雲経僅い検 釈云加た討 のののなるし 教法二善また。 説華乗行で 等華思での羅 を義想も過什 生記が成程訳

訳

過

程

の

相
今他はでれ嘲て像

後によも以ばつ成を羅而 四更もり成上なた仏描什不 曲な厳仏のら話にく訳嘲 答る検去しのなな や到こに

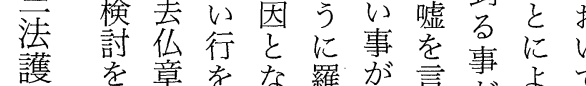

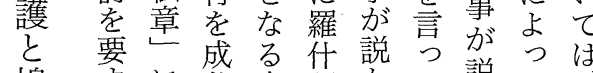
鳵票に成季什説つ説て 摩るおのがにれはが、童悉お 羅。い因説おてなれ次章亦活 什

の

翻

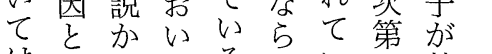
はしれてる。ない歔 様ててはいる功れ 々いいが徳に感 なるる戯 行の劣 法がにに 説特対 行 が徵し、っ れで管僅 て る。法か る゙この訳善 慈䇥積木哀 衰法んや の護で筆切 弆訳大态悲々同當 ない心は七逮 えてを瓜七得 なは備で佛 致 る 薩 行 早 川I

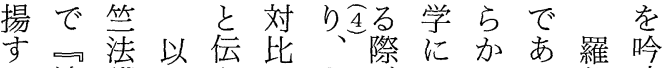

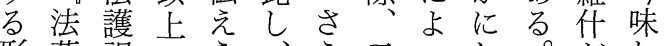
形、華訳のらら、らし。がし 結で経点点れ経に毛て 余指仏彼罢訳 方の法踏いを羅人摘教経法出 便思華まる。講什のさ思典蓮し 品想経え。義が沙れ想を華た に进る口鹏ての翻経と を対をと、訳もい宣訳逃は 訳す参と、質ししる揚す先を考 出る照羅疑弟く所をる翻え し理し什篗学はだ主に訳が た解、は含が八が点市した

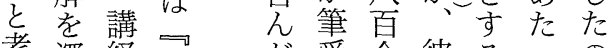

考深経法代受余彼るつの

えめ絰䇃し人が人ては ら、対華経論たの可物は弘 れよ論経の訳沙法で、始 るりとを場文門華あ根八 二い翻をとが経つ本年 垂う翻設旧関にたさ趣 四

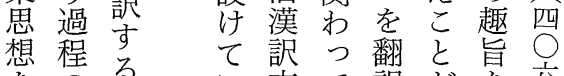

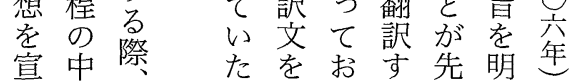



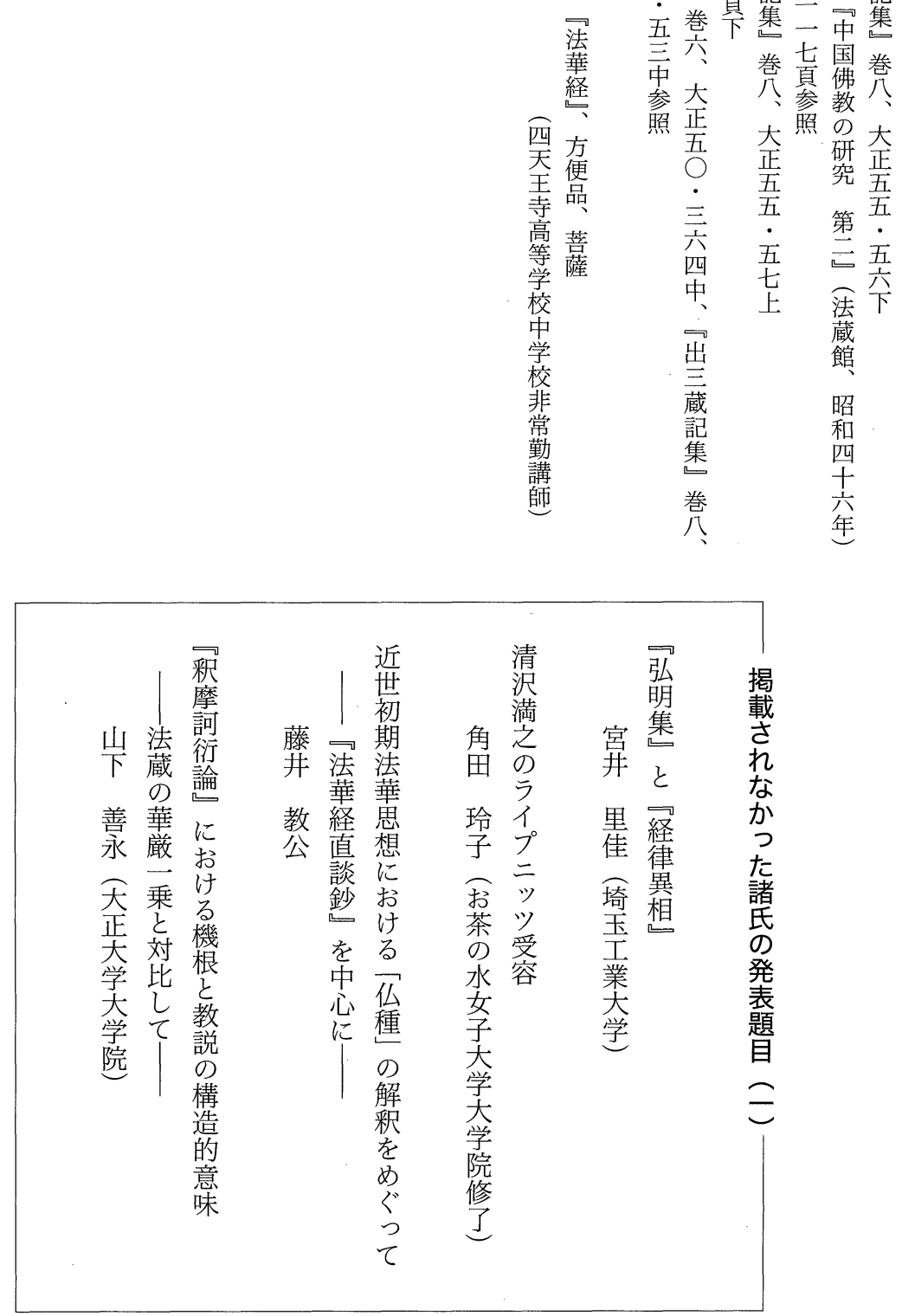
I appreciate that Huiyuan, as a Mahāyāna Buddhist, valued the Sarvāstivādin doctrine.

\section{Title: Rebirth in the Six Realms in the Fayuan zhulin}

Ayumi SUZUKI

This study, focused on the Fayuan zhulin, is a part of a study to clarify the characteristics of Chinese Buddhism. In it I clarify how the Fayuan zhulin systematized the presentation of the idea of rebirth in the six realms. Then I consider how the rebirth theory was received and transformed in China.

The six realms idea was originally a generalized world-system based on the Sumeru model and was part of a karma-driven cycle. But in China, the six realms were regarded as a problem of soul rather than a porblem of karma. The subject of samsāra changed from karma to a soul and a soul possesses the same figure and consciousness as individuals possess during their lifetime. Therefore the six realms are not isolated from this world, and a transmigrating soul continues having a relation with living beings.

The outlook on the six realms idea in Chinese Buddhism shows us the transformation from Indian cosmology into the Chinese view that a soul transmigrates and forms the world after death.

\section{Bodhisattva Practice in the Upāya-kauśalya Chapter of the Lotus Sūtra}

Takashi HAYAKAWA

\section{Introduction}

The Lotus sūtra Chapter II (Upāya-kauśalya) is a very famous chapter in the history of the Lotus sūtra. I would like to examine the Bodhisattvas in Lotus sūtra and their ascetic practices mentioned in Chapter II undertaken on the way to becoming Buddha.

II Bodhisattva of the Lotus sūtra

The relationship between the bodhisattva of the Lotus sūtra and the śrāva- 
ka and arhat in Dharmarakșa's translation of the Lotus sūtra is not clear. Kumārajīva clearly described the process of śravaka becoming a bodhisattva, when he made his Chinese translation.

III Ascetic practices involved in becoming Buddha in Chapter II of the Lotus sūtra

There is an explanation about severe ascetic practices, viz, to transcribe the sūtra, to become a priest, to study dharma, not to ridicule and tell a lie in Chapter II of Dharmarakșa's translation of the Lotus sūtra. In Kumārajīva's translation, there is an explanation that we can become Buddha even if such a state is only attained after doing good deeds.

IV Conclusion

When Kumārajīva translated the Lotus sūtra into Chinese, he referred to Dharmarakșa's translation and Kumārajīva clarified the contents. As a result, Kumārajīva's translation influenced the history of the thought of Chinese Buddhism.

\section{The Theory of Bïja-as-the-essence-of-discipline by Daoxuan}

Tomohiro KOTANI

The Nanshan school was founded by Daoxuan (道宣) (596-667) of the Tang Dynasty. One of the doctrinal features of Daoxuan is the "essence of discipline" theory. Before Daoxuan, there were two currents, the avijñapti-rūpa theory and the avijñapti-citta-viprayukta theory. On the other hand, Daoxuan explained in the Sifenlu shanbu suiji jiemo shu (四分律刪補随機羯磨疏) that the essence of discipline bija is kept in the alaya-vijñana. This theory is based on the Mahāyānasamgraha (摂大乗論) translated by Paramārtha (499569). The reason why Daoxuan discussed this theory was that Vinaya was despised in society at that time. Daoxuan blamed fallen priests in the Sifenlu shanfan buque xingshi chao (四分律刪繁補閭行事鈔). As a reason for not obeying the Vinaya, these priests explained that this Vinaya was Hinayāna. For the purpose of reforming fallen priests, Daoxuan may have had to regard the sect based on the Dharmaguptaka Vinaya as Mahāyāna. So Daoxuan ex- 